trated in Figure 2. A transition to a state with no overturning circulation in the Atlantic Ocean occurs if the maximum warming exceeds a certain threshold. In addition to the level of achieved warming, also the rate of the warming is crucial. Faster warmings lead to lower thresholds, while slower warming makes the system more permissible and a larger warming can be achieved without a cessation of the overturning circulation. This was the first indication of a physical process which caused fundamentally different climate responses might result from slightly different emissions scenarios. These findings make a strong case for "early action" on $\mathrm{CO}_{2}$ emissions reductions in order to keep away from potentially dangerous thresholds.

The increasing quality of paleoclimatic records, and the establish- ment of reliable time scales now allow the investigation of the rate of change of certain quantities. Such information provides important constraints for models simulating past climate changes. The quantification of $\mathrm{CO}_{2}$ rates is potentially important in helping to disentangle the different mechanisms that are responsible for the observed changes. $\mathrm{CO}_{2}$ rate will also play a crucial role in future climate change since they influence the proximity of certain thresholds in the climate system. Such thresholds could hold unwanted surprises of change. By paying special attention to $\mathrm{CO}_{2}$ growth rates, and their possible limitation by carefully selecting emission paths in the future, such surprises may be successfully avoided (Alley et al., 2003).

\section{REFerences}

Alley, R.B., Marotzke, J., Nordhaus, W.D., Overpeck, J.T., Peteet, D.M., Pielke Jr., R.M., Pierrehumbert, R.T., Rhines, P.B., Stocker, T.F., Talley L.D. and Wallace, J.M., 2003: Abrupt climate change. Science, in press.

Blunier, T., Chappellaz, J., Schwander, J., Dällenbach, A., Stauffer, B., Stocker, T.F., Raynaud, D., Jouzel, J., Clausen, H.B., Hammer, C.U. and Johnsen, S.J., 1998: Asynchrony of Antarctic and Greenland climate change during the last glacial period. Nature, 394, 739-743.

Indermühle, A., Stocker, T.F., Joos, F., Fischer, H., Smith, H.J., Wahlen, M., Deck, B., Mastroianni, D. Tschumi, J., Blunier, T., Meyer, R. and Stauffer, B., 1999: Holocene carbon-cycle dynamics based on $\mathrm{CO}_{2}$ trapped in ice at Taylor Dome, Antarctica. Nature, 398, 121-126.

IPCC, 2001: Climate Change 2001: The Scientific Basis. Contribution of Working Group I to the Third Assessment Report of the Intergovernmental Panel on Climate Change. [Houghton, J.T., et al. (eds.)]. Cambridge University Press, Cambridge, $881 \mathrm{pp}$.

Stocker, T.F. and Wright, D.G., 1991: Rapid transitions of the oceans deep circulation induced by changes in surface water fluxes. Nature, 351, 729-732.

For full references please consult:

www.pages-igbp.org/products/newsletters/ref2003_1.html

\title{
Rates of Change in the Upper Treeline Ecotone in the Polar Ural Mountains
}

\author{
Stepan G. Shiyatov
}

Institute of Plant and Animal Ecology (Ural Branch of the Russian Academy of Sciences), 620144 Ekaterinburg, Russia, stepan@ipae.uran.ru

Significant spatio-temporal changes took place in the upper treeline ecotone in the Polar Ural Mountains $\left(66-67^{\circ} \mathrm{N}, 65-66^{\circ} \mathrm{E}\right)$ during the last millennium (Shiyatov, 1993, 1995). Within the treeline ecotone, which is located from 100 to $350 \mathrm{~m}$ a.s.l., Siberian larch (Larix sibirica) open forests dominate. Patches of larchspruce (Picea obovata) closed forests grow at lower altitudinal levels in the ecotone. Up to this day, these forests have been mainly developing under the influence of natural factors. There are a great number of wood remnants on the ground up to $60-80 \mathrm{~m}$ above the present treeline and within the ecotone that have been preserved for a long time (up to 1300 years) because of the low rate of wood decomposition in severe climatic conditions. These provide us with the possibility of extending ring-width chronology back to $645 \mathrm{AD}$ and of dating the lifetime of a large quantity of dead trees. In order to estimate displacement of the upper treeline (the highest

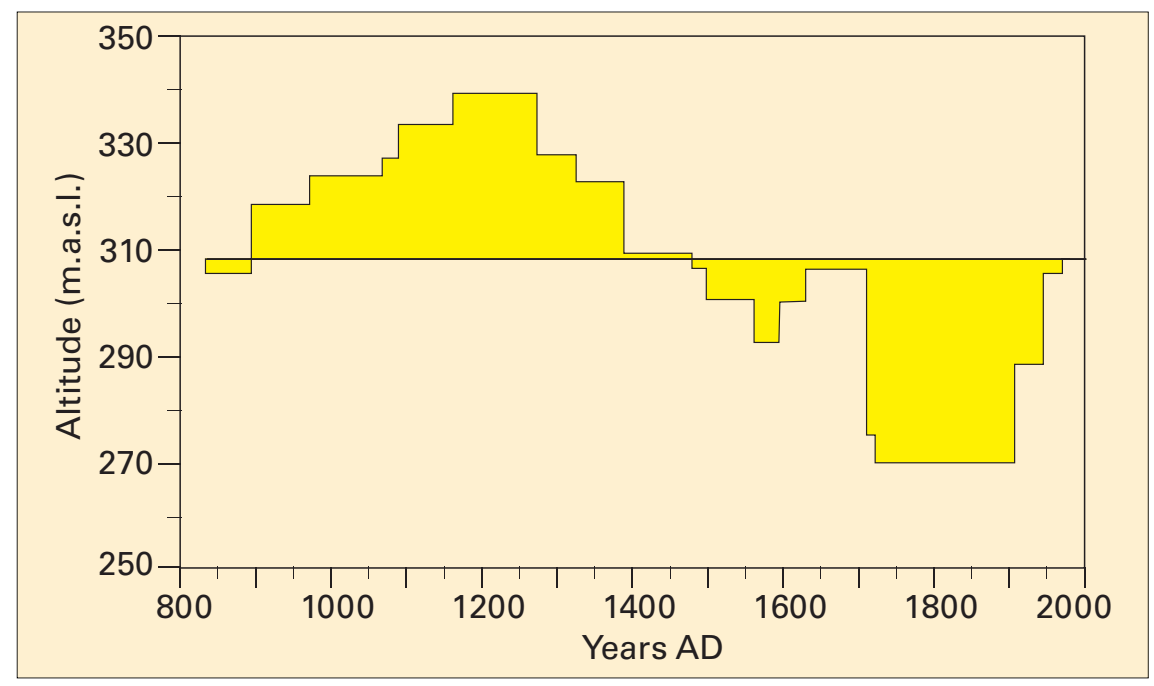

Fig. 1. Altitudinal displacement of the upper treeline in the Polar Ural Mountains during the last 1150 years.

altitudinal position of open forests) over the last millennium, a transect $430 \mathrm{~m}$ long and $20 \mathrm{~m}$ wide was set up on the south-eastern slope of Rai-Iz Massif, from the highest location of larch wood remnants (340 $\mathrm{m}$ a.s.l.) to the present upper treeline $(280 \mathrm{~m})$. The transect was divided into $10 \times 10 \mathrm{~m}$ quadrates. All of the wood remnants were mapped and cuts from the base of trunk and roots were collected from each individual tree. Calendar years of establishment and dying off were determined by dendrochronological techniques. Altogether, a time span of 270 dead trees was defined. In addition, 16 young living trees and seedlings were also mapped and their age determined. 


\section{Science Highlights}

Table 1: Area changes of different types of forest-tundra ecosystems from 1910 to 2000

\begin{tabular}{|l|c|c|c|c|}
\hline \multirow{2}{*}{ Time } & \multicolumn{4}{|c|}{ Forest Tundra Ecosystem Types } \\
\cline { 2 - 5 } & $\begin{array}{c}\text { Tundra with } \\
\text { Individual Trees }\end{array}$ & $\begin{array}{c}\text { Sparse Growth } \\
\text { of Trees }\end{array}$ & Open Forest & Closed Forest \\
\hline $\mathbf{1 9 1 0}$ & 2403 ha & 349 ha & 328 ha & 5 ha \\
\hline $\begin{array}{l}\text { Rate of } \\
\text { Change }\end{array}$ & -76 ha/decade & +37 ha/decade & +24 ha/decade & +15 ha/decade \\
\hline $\mathbf{1 9 6 0}$ & 2021 ha & 535 ha & 450 ha & 79 ha \\
\hline $\begin{array}{l}\text { Rate of } \\
\text { Change }\end{array}$ & -26 ha/decade & -52 ha/decade & +36 ha/decade & +42 ha/decade \\
\hline $\mathbf{2 0 0 0}$ & 1917 ha & 327 ha & 593 ha & 258 ha \\
\hline
\end{tabular}

Using this data, upper treeline displacement over the last 1150 years was reconstructed (Fig. 1). This time interval was divided into 5 periods, distinguished by differing directions of treeline shifting (rising or retreating) and differing rates of displacement. During the earliest period (430 years, 850-1280 AD), the upper treeline rose from 305 to $340 \mathrm{~m}$ a.s.l., i.e. 1-2 m/dec on average. The highest altitudinal position reached by the treeline and the densest and most productive larch stands observed in the last millennium were in the $13^{\text {th }}$ century. The second period (300 years, $1280-1580 A D$ ) was characterized by a severe retreat of the upper treeline (from 340 to $295 \mathrm{~m}$ ) at a mean rate of $2-3 \mathrm{~m} / \mathrm{dec}$. During the third period (210 years, 1580-1790 AD), the treeline retreat stopped. The observed rise (from 295 to $305 \mathrm{~m}, 0.5-1.0 \mathrm{~m} / \mathrm{dec}$ ) was not significant. The most extreme retreat was seen in the fourth period (120 years, 1790-1910 AD), during which the upper treeline receded from 305 to $270 \mathrm{~m}$, i.e. $2-4 \mathrm{~m} / \mathrm{dec}$. During this period, the upper treeline was at its lowest altitudinal position for the millennium. In the last period, from 1910 to the present day, intensive afforestation took place on sites that were forested during the Middle Ages. The rate of change was the highest for the millennium (from 270 to $308 \mathrm{~m}, 4-6 \mathrm{~m} / \mathrm{dec}$ ).

We are currently carrying out intensive studies of the last period of expansion of forest vegetation using both direct and indirect evidence (old terrestrial, aerial and satellite photographs, repeated stand descriptions of permanent plots and transects, morphological and age structure of stands, large-scale mapping within the ecotone, meteorological and dendroclimatic data).

Table 1 shows changes in area under different types of forest-tundra ecosystems within the ecotone during the $20^{\text {th }}$ century. These data were obtained at the time of large-scale $(1: 10000)$ mapping of the key area (3085 ha) located at the bottom of the Tchernaya Mountain. Altogether, we obtained three maps, which show a spatial distribution of these types of forest-tundra ecosystems for the beginning, middle and end of the century. We made a quantitative estimation of the change in their area during two periods; 50 years from 1910 to 1960, and 40 years from 1960 to 2000.

Over these 90 years, the area under tundra with individual trees decreased significantly from 2403 to 1917 ha, or from 78 to $62 \%$ of the key area. The greatest rate of change (-76 ha/dec) was observed during the first 50 years, when isolated seedling establishment above the treeline was the most intensive. Data obtained on the area change

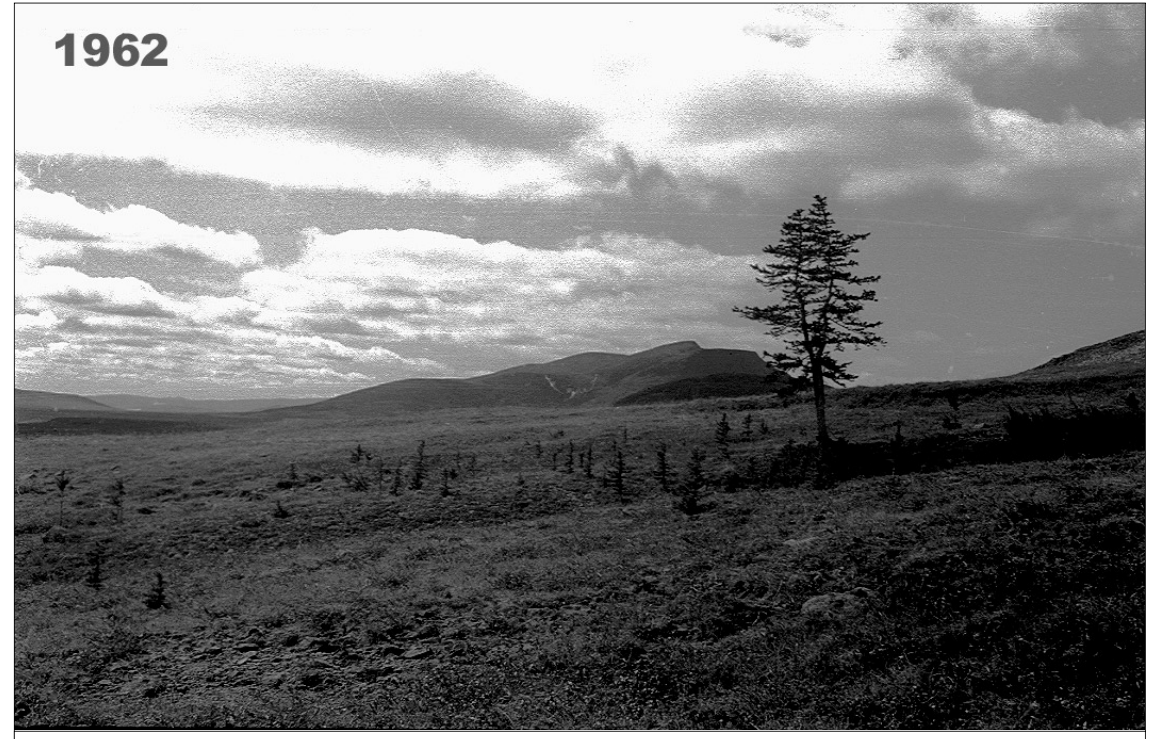

\section{2}

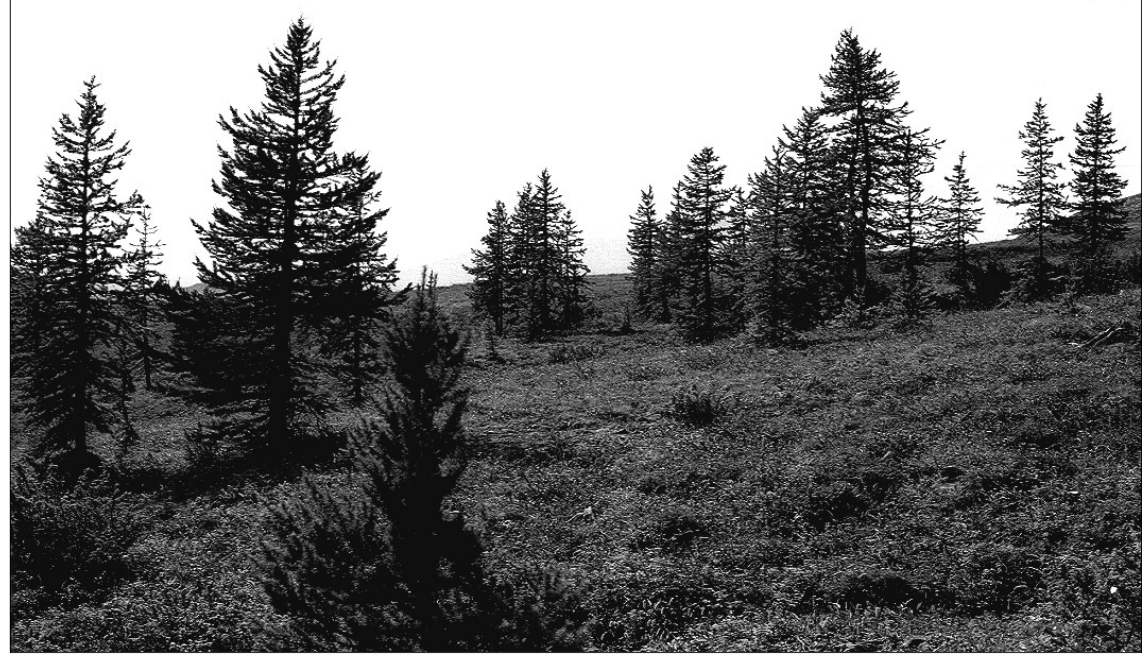

Fig. 2: Photographs taken from the same point, which show the formation of open larch forest on tundra with individual trees during the last 40 years. 
of the sparse growth of trees is very interesting since during the first period the rate of change was positive $(+37 \mathrm{ha} / \mathrm{dec})$ but during the second period it was negative $(-52 \mathrm{ha} / \mathrm{dec})$. The decrease was caused when young established trees began producing seeds and as a result the density of stands increased (many of them turned into open forest). It is for this reason that the increase in area under open forest was so great during the period from 1960 to $14.3^{\circ} \mathrm{C}$. Mean temperatures in the winter months (November-March) increased from $-20.8^{\circ} \mathrm{C}$ to $-19.6^{\circ} \mathrm{C}$. Critical for tree growth, the average June-July temperature increased from $10.5^{\circ} \mathrm{C}$ to $11.4^{\circ} \mathrm{C}$, or by $0.9^{\circ} \mathrm{C}$. This means that the June-July isotherm rose $120-130 \mathrm{~m}$ in altitude (in this area the gradient is $0.7^{\circ} \mathrm{C} / 100 \mathrm{~m}$ ). However, the upper treeline did not rise to this altitude. In fact, the mean rise was only $20-40 \mathrm{~m}$. The main reason for this was a deficiency of

Table 2: Rates of Change within the treeline ecotone on the eastern slope of the Polar Ural Mountains (Sob River basin, 66-67 N, 65-66 $6^{\circ}$ ) during the last 1150 years

\begin{tabular}{|c|c|c|}
\hline Climate Variable / Proxy & Modern Rate of Change & Past Rate of Change \\
\hline \multirow[t]{4}{*}{ Treeline Displacement } & \multirow[t]{4}{*}{$\begin{array}{l}\text { Rise: } 4-6 \mathrm{~m} / \text { decade } \\
(1910-2000 \mathrm{AD})\end{array}$} & $\begin{array}{l}\text { Rise: } 1-2 \mathrm{~m} / \text { decade }(850-1280 \mathrm{AD}, \\
430 \text { years) }\end{array}$ \\
\hline & & $\begin{array}{l}\text { Retreat: } 2-3 \mathrm{~m} / \text { decade }(1280-1580 \mathrm{AD} \text {, } \\
300 \text { years) }\end{array}$ \\
\hline & & $\begin{array}{l}\text { Rise: } 0.5-1.0 \mathrm{~m} / \text { decade }(1580-1790 \mathrm{AD} \text {, } \\
210 \text { years) }\end{array}$ \\
\hline & & $\begin{array}{l}\text { Retreat: } 2-4 \mathrm{~m} / \text { decade }(1790-1910 \mathrm{AD} \text {, } \\
120 \text { years) }\end{array}$ \\
\hline $\begin{array}{l}\text { Degree of Afforestation } \\
\text { (within the treeline } \\
\text { ecotone) }\end{array}$ & $\begin{array}{l}+2 \% / \text { decade } \\
(1910-2000 \text { AD) }\end{array}$ & \\
\hline
\end{tabular}

to 2000 (from 450 to 593 ha, +36 ha/dec). However, the most impressive changes were seen with closed forests. The area increased from 5 to 258 ha over the 90 years with the transformation of open forests into closed forests.

Two terrestrial photographs taken from the same point in 1962 and 2002 (Fig. 2) show an example of forest expansion during the last century. Only one middle-aged larch tree and several seedlings up to $1 \mathrm{~m}$ in height were established between 1910 and 1960. Now, however, a typical open forest has developed on the site and new seedling establishment is taking place (Fig. 2). To date, we have taken more than 550 repeated terrestrial photographs, which can be used to reconstruct stand parameters for the middle of the $20^{\text {th }}$ century.

Warming during the $20^{\text {th }}$ century was the major cause of spatio-temporal expansion of trees in the treeline ecotone. The mean temperature for June at Salekhard weather station $(50 \mathrm{~km}$ to the east of the study area) increased from $7.2^{\circ} \mathrm{C}$ (1883-1919) to $8.5^{\circ} \mathrm{C}$ (1920-1998). The mean for July increased from $13.8^{\circ} \mathrm{C}$ viable seeds on sites remote from fertile trees and stands.

We revealed earlier (Shiyatov, 1966), that the opening of larch cones and subsequent seed dissemination occur only on days of elevated temperatures (such as occur from the end of June to the end of July). Wind is the primary method of seed dissemination, with the influence of other methods, such as animals and birds, being insignificant. Since seed dissemination takes place in summer when snow cover is absent, it is difficult for seeds to be transported upwards over long distances. Heavy larch seeds are carried no more then $40-60 \mathrm{~m}$ from a tree and most of these seeds become stuck in the lichen-moss and shrub layers. That is why abundant seedling establishment took place only close to individual trees (Fig. 2) and within stands.

Impressive changes have occurred in the structure of existing stands during the 90 years. Most of them have become much denser and more productive (up to 4-5 times) and many tundra sites located within the treeline ecotone have been afforested. The degree of afforestation increased from 22 to $38 \%$ (calculation based on data from Table 1). Thus, many parameters affecting forest-tundra ecosystems react well to summer temperature changes. For the purpose of climatic reconstruction, the best are those obtained from existing stands (tree rings, biomass, density of stand and canopy, degree of afforestation). Although the displacement rate of the upper treeline is a good reflection of long-term climatic fluctuations (Table 2), reconstruction of actual temperature changes is complicated because of the response lag caused by the slow growth of seedlings and the lack of seeds on remote sites. For example, the recent warming observed in summer months is of the same degree seen in the Middle Ages (about $1^{\circ} \mathrm{C}$ ) but the upper treeline has not reached the altitudinal position on which forests grew in the $13^{\text {th }}$ century. To overcome such discrepancies, it is necessary to use corrective factors. These will be different for each period and study area. For example, in the Polar Ural Mountains over the 90 years, the upper treeline rose $20-40 \mathrm{~m}$ in altitude but the June-July temperature isotherm rose $120-130 \mathrm{~m}$. Therefore, reconstructed temperatures based on this parameter should be increased by a factor of 4 .

\section{AcKnowledgements}

This study was financially supported by the Russian Foundation of Basic Research, grants 99-04-48984 and 02-04-48180.

\section{REFERENCES}

Shiyatov, S.G., 1966: The time of dispersion of Siberian larch seeds in north-western part of its areal space and role of that factor in mutual relation between forest and tundra. In: Problems of physiology and geobotany. Publication of the Sverdlovsk Branch of the All-Union Botanical Society, Issue 4, 109-113 (in Russian).

Shiyatov, S.G., 1993: The upper timberline dynamics during the last 1100 years in the Polar Ural Mountains. In: Oscillations of the alpine and polar tree limits in the Holocene led. by Burkhard Frenzel. Co-ed. by Matti Eronen and Brigit Glaser). Gustav Fischer Verlag: Stuttgart, Jena, New York, 195-203.

Shiyatov, S.G., 1995: Reconstruction of climate and the upper timberline dynamics since AD 745 by tree-ring data in the Polar Ural Mountains. Publication of the Academy of Finland, 6/95, Painatuskeskus, 144-147. 